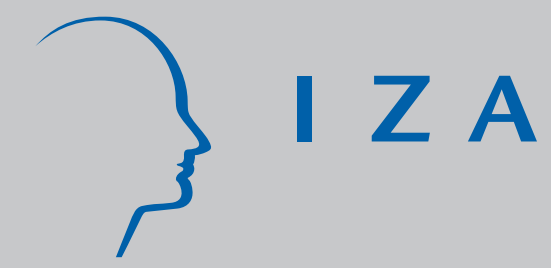

IZA DP No. 361

Worker Training in a Restructuring Economy: Evidence from the Russian Transition

Mark C. Berger

J ohn S. Earle

Klara Z. Sabirianova

September 2001 


\title{
Worker Training in a Restructuring Economy: Evidence from the Russian Transition
}

Mark C. Berger

Department of Economics, University of Kentucky and IZA, Bonn

John S. Earle

SITE, Stockholm School of Economics, Central European University and IZA, Bonn

Klara Z. Sabirianova

William Davidson Institute, University of Michigan Business School and IZA, Bonn

Discussion Paper No. 361

September 2001

\author{
IZA \\ P.O. Box 7240 \\ D-53072 Bonn \\ Germany \\ Tel.: +49-228-3894-0 \\ Fax: +49-228-3894-210 \\ Email: iza@iza.org
}

This Discussion Paper is issued within the framework of IZA's research area Labor Markets in Transition. Any opinions expressed here are those of the author(s) and not those of the institute. Research disseminated by IZA may include views on policy, but the institute itself takes no institutional policy positions.

The Institute for the Study of Labor (IZA) in Bonn is a local and virtual international research center and a place of communication between science, politics and business. IZA is an independent, nonprofit limited liability company (Gesellschaft mit beschränkter Haftung) supported by the Deutsche Post AG. The center is associated with the University of Bonn and offers a stimulating research environment through its research networks, research support, and visitors and doctoral programs. IZA engages in (i) original and internationally competitive research in all fields of labor economics, (ii) development of policy concepts, and (iii) dissemination of research results and concepts to the interested public. The current research program deals with (1) mobility and flexibility of labor markets, (2) internationalization of labor markets and European integration, (3) the welfare state and labor markets, (4) labor markets in transition, (5) the future of work, (6) project evaluation and (7) general labor economics.

IZA Discussion Papers often represent preliminary work and are circulated to encourage discussion. Citation of such a paper should account for its provisional character. 


\section{ABSTRACT \\ Worker Training in a Restructuring Economy: Evidence from the Russian Transition*}

We use 1994-1998 data from the Russian Longitudinal Monitoring Survey (RLMS) to measure the incidence and determinants of several types of worker training and to estimate the effects of training on workers' interindustry, interfirm, and occupational mobility, their labor force transitions, and their wage growth in Russia compared to the U.S. We hypothesize that the shock of economic liberalization in Russia may raise the benefits of training, particularly retraining for new jobs, but uncertainty concerning the revaluation of skills may raise the costs, with an overall ambiguous effect on the amount of training undertaken. The RLMS indicates a lower rate of formal training than studies have found for the U.S., suggesting that the second effect dominates. Previous schooling is estimated to affect the probability of training positively, but the relationship is much stronger for additional training in the same field than for retraining for new fields, consistent with the hypothesis that schooling and training are complementary but become more substitutable in a restructuring environment. Additional training in workers' current fields is estimated to reduce mobility and earnings, suggesting inertial programs from the pre-transition era. Retraining in new fields increases all types of worker mobility and has higher returns than those typically observed for training in the U.S., but it also raises the variance of earnings and the probability of unemployment, consistent with a search view of such retraining. Given the large returns to retraining, the efforts of Russian workers to learn new skills may increase as uncertainty is resolved and restructuring proceeds.

JEL Classification: J3, J4

Keywords: On-the-job training, restructuring, wage growth, human capital investments

Mark C. Berger

Department of Economics

335 Gatton Building

University of Kentucky

Lexington, KY 40506-0034

Tel.: +1 (859) 257-1282

Fax: +1 (859) 257-7671

Email: mberger@pop.uky.edu

\footnotetext{
* We acknowledge the helpful comments of Barry Ickes, Rostislav Kapelyushnikov, Dan Black and participants at sessions at the annual meetings of the American Economic Association in Boston and New Orleans, and the European Society of Population Economics in Bonn, Germany.
} 


\section{INTRODUCTION}

Worker training appears to play a central role in economic restructuring. When rapid structural change in technology or markets alter the relative value of various skills, training and retraining may be beneficial in facilitating the reallocation of labor to higher-valued uses. Despite the presence of such structural change in most modern economies, however, there has been rather little research on the influence of restructuring on the extent and nature of private-sector training decisions. Compared to training activities over the worker and job life cycle, the focus of most prior research, is more training actually undertaken by workers and firms in the restructuring context? How does structural change affect the determinants of training, in particular the relationship with prior formal schooling? Finally, what are the labor market consequences of training - including employment, wages, and job mobility in a restructuring environment?

In this paper, we investigate these questions drawing upon the example of Russia, an economy undergoing vast structural changes in the 1990s. As in other transition economies, the socialist legacy of inefficiency in enterprise functioning and the large shifts in the demand for various types of labor associated with the initial shocks of transition suggest that workers should acquire new skills to be able to work with new technologies and to meet the demands of a market economy. Our underlying premise is that the magnitude and suddenness of the shock to the valuation of various types of skills in Russia may provide some general lessons on the role of training in the process of economic restructuring. Our empirical analysis employs a household panel data set, the Russian Longitudinal Monitoring Survey (RLMS), for the years 1994 to 1998. We also compare our results with the empirical findings concerning private-sector training in stable market economies such as the U.S.

We argue that the restructuring context may raise the benefits of training, but the effects on the amount, the determinants, and the productivity of 
training are ambiguous. To start with, it is possible that the costs of trainingparticularly those faced by firms and workers - may also increase. If the new structure of returns to skill types is initially unknown, or only partly observed, then risk-averse agents may be reluctant to undertake investments. Only gradually, as relative price movements settle down, and search and experimentation with skill acquisition of various types unfolds, will the new earnings structure be revealed. Uncertainty about the new returns and their future evolution may therefore depress training activities, analogously to Bartel and Sicherman's (1998) argument that technological change may reduce training because of the possible future obsolence of the skills acquired. A further implication is that the uncertainty associated with the shock may be reflected in a high variance in the outcomes of training.

In applying these arguments to an empirical analysis of training in a restructuring economy, we argue that a crucial distinction, albeit not entirely unambiguous, concerns the difference between retraining - the acquisition of new skills that are useful for changing jobs and thus for promoting labor reallocation - on the one hand, and types of additional training that simply enhance existing skills, on the other. While other studies using Western data have considered various components of total training (e.g., Barron, Berger, and Black, 1997; Lillard and Tan, 1992; Loewenstein and Spletzer, 1997, 1999a, 1999b; Lynch, 1992; Lynch and Black, 1998; Parent, 1999; Veum, 1993, 1995, 1997), none have disaggregated total training into retraining in different fields and additional training in the same field. Throughout the paper, we illustrate the utility of this distinction, examining both the determinants and the consequences of these two types of training. 


\section{WORKER TRAINING IN TRANSITION}

Russia in transition offers an unusual opportunity to examine the role of job training in a setting where there has been a large amount of structural change. The magnitudes of the changes dwarf what have been experienced in western economies due to plant closings, shifts in industrial and occupation demands, economic liberalization and the rise of market competition. Here we use this quasi-experiment to understand the incidence of various types of training and the effects of training on mobility and wages in the restructuring context.

There is no evidence on the effects of training using direct measures of training for the transition economies, aside from research on the impact of government training and other active labor market programs for reemployment of the unemployed in Central Europe (e.g., O’Leary, 1997; Earle and Pauna, 1998; O’Leary, Kolodziejczyk, and Lazar, 1998; Kluve, Lehmann, and Schmidt, 1999; Terrell and Sorm, 1999; Lubyova and van Ours, 1999; and Lechner, 2000). While there have been studies of labor mobility in transition economies, none explicitly examines the relationship between training and mobility (Boeri and Flinn, 1999; Orazem and Vodopivec, 1997). To our knowledge, there are no studies of transition economies that attempt an overall quantification of the incidence of formal training, nor that estimate the determinants and effects of training on standard labor market outcomes.

We first consider the impact of restructuring on the amount of training. After decades of central planning, including strict controls on prices, wages, and all forms of economic activity, liberalization policies resulted in a drastic revaluation of activities and skills. If there is little uncertainty concerning the revaluation, then restructuring should raise the amount of training as workers shift their efforts to higher valued uses. But if uncertainty increases simultaneously, then risk-averse workers and firms may be less likely to undertake training. Our analysis has some similarity with Bartel and 
Sicherman's $(1998,1999)$ discussion of technological change, where the relationship between the amount of training and the average rates of technological change in an industry may be ambiguous due to uncertainty concerning the extent to which the skills imparted by training become obsolete.

The economic transition in post-socialist countries, however, was more akin to a one-time shock, particularly in countries such as Russia that adopted "big-bang" liberalizations. The shock was so large that it produced considerable uncertainty about the nature of the skill revaluation. Only gradually have workers and firms been able to learn, partly through experimentation and experience, where the new opportunities lie. Moreover, the severity of the recession, the lack of liquidity, and possibly a lack of qualified trainers imply that formal programs are likely to be prohibitively expensive in the current environment. Thus, while it seems clear that the social value of training increases with the extent of resource misallocation and the necessity for restructuring, uncertainty and various constraints may result in less training than in a stable economy. These theoretical considerations imply an ambiguous relationship.

An important distinction in analyzing training in the restructuring context concerns the relationship between a worker's existing skill set and the skills taught in training programs. Training under restructuring may be a response to the shifts in labor demand across occupations and industries; in this case it would represent a more radical departure from the worker's previous skills rather than simple enhancement of the skill sets workers had at the beginning of transition. Although the distinction between these two types of training (additional training for the same tasks as the current job versus retraining in other fields) has not been analyzed in the Western training literature, it would appear to be particularly important for a restructuring economy such that in Russia. On the other hand, additional training could still be sizable because of inertia in the activities of training institutions inherited 
from the Soviet economic system, which organized a large amount of formal training - much of it through apprenticeships and specialized suborganizations within firms. In fact, during the Soviet era, virtually every worker went through a formal program to provide additional training in his or her current job every five to seven years.

The skills taught in these programs may have much lower value than they did formerly, and the acquisition of these skills may tend to reduce rather than enhance worker mobility. This also suggests that such firm characteristics as ownership (reflecting corporate governance issues) and size (which has been found by Lowenstein and Spletzer (1999b) and Veum (1995) to be positively associated with training) may be important determinants of training in the restructuring context.

Another adjustment problem is a possible shortage of trainers, particularly when the magnitude of structural change is such that wholly new skills are in demand. In sectors such as financial services, retail trade, and marketing, as well as new systems of accounting, where there was a nearly complete vacuum of skills at the beginning of transition, for instance, there may be very little opportunity for workers to obtain training. A shortage of trainers in new fields may tend to reinforce the inertial tendency for existing institutions to continue training in old fields, even if it produces a small or even possibly negative return. Indeed, we would argue that the degree to which training in Russia is dominated by retraining for new types of jobs may be taken as one indicator of the extent to which such obstacles have been overcome and genuine restructuring of the labor force is underway.

Next, we turn to the determinants of training decisions: the relationship between the probability of training and the characteristics of workers and their employers. A first issue is the degree of complementarity or substitutability of formal schooling with subsequent training. Standard human capital theory going back to at least Mincer (1962) argues that different types of skill acquisition are complementary, and Veum (1995), Loewenstein and Spletzer 
(1999b), and Bartel and Sicherman (1998) have provided recent evidence in support of the positive schooling-training correlation. Empirical verification is hampered, however, by the possibility that schooling, subsequent skill acquisition, and career decisions are jointly determined. For instance, suppose that individuals have some unobserved "tolerance for change" that is associated with lower costs of formal schooling and training and also influences occupational choices (raising the attractiveness of fields in which change is more likely). Then the observation of a positive correlation between schooling and training may not reflect any complementarity of the two kinds of skill acquisition. In the transition context, however, the magnitude of the revaluation of skills was completely unforeseen, and educational choices by workers in our 1994 sample were made with little expectation of the shocks to come. Therefore, we can treat educational choices as exogenous with respect to subsequent training decisions, particularly where the latter involves retraining for new fields.

For western economies, the closest line of research to the question of the effect of restructuring on training activities is the work of Bartel and Sicherman (1998, 1999), who use NLSY data to examine technological change and the acquisition of training. They present evidence that production workers in industries with higher rates of technological change are more likely to receive formal company training and that the training gap between high and low educated workers narrows. The argument that schooling and training become more substitutable in an environment of rapid change may be extrapolated to the restructuring environment, implying that we should observe a lower level of complementarity between schooling and training, particularly when we analyze retraining for other fields.

Another important aspect of inherited human capital in the transition concerns previous work experience and job tenure as proxies for informal onthe-job training. Bartel and Sicherman (1998) among others, report positive relationships between both of these variables and the probability of training 
(defined as formal, company-organized training). The positive association may be interpreted as evidence of complementarity among the types of human capital investment, but that interpretation is open to the objection that experience and more particularly job tenure may be endogenous. We can again exploit the unexpected nature of the transition to argue that previous job tenure is exogenous, thus providing a cleaner test of these relationships.

Some characteristics of firms, associated with the propensity to undertake restructuring, may also have an impact on training. Perhaps the most interesting hypothesis in the transition context concerns the relationship of firm ownership with the two types of training we have distinguished: additional training of workers in the same field and retraining in other fields. Here we would argue that corporate governance considerations suggest that firms that have been privatized to foreign investors or other controlling outsiders may be more likely to adopt new technologies and change job assignments, possibly requiring greater retraining of their workers. If retraining in a new field is taken as representing restructuring, while additional training in the same field is not (reflecting instead a lack of response to new incentives), then such firm characteristics may have different relationships with the different types of training.

With respect to the consequences of training, we investigate several types of worker mobility and wage growth. A growing body of research has examined labor mobility in Western economies, but very few have explicitly examined the relationship between training and labor mobility. Parent (1999) uses NLSY data and finds that training provided by employers reduces interfirm mobility. Loewenstein and Spletzer (1997, 1999a) also find a negative relationship between training and mobility using NLSY data. However, they argue that the causation in part may go the other way. Employers belatedly find out which employees are less mobile and are more likely to invest in their training. Veum (1997) also uses the NLSY and finds limited evidence that company training reduces turnover. Felstead, Green, 
Mayhew, and Pack (1999), using British survey data, find that training has little if any impact on mobility.

Again, we argue that the restructuring context matters: if our conjecture that the return to switching firms, industries or occupations in Russia may be much greater than in the standard setting of a stable market economy, then training may lead to higher rather than lower quits from the firm, as well as increased mobility across industries and occupations. The positive impact of training on quits should be much more pronounced for retraining in new fields, and it could be zero or negative for additional training.

Finally, concerning the impact of training on wage growth, it strikes us that a restructuring economy should have many possibilities for productive, wage-increasing labor mobility, if the necessary new skills can be acquired. Since mobility in general, and skill acquisition in particular, are costly processes, the revalued occupations may pay significant rents for some time before labor supply adjustments are complete. If this reasoning is correct, then the return to training in Russia should be higher than in the U.S. On the other hand, if much Russian training results from the inertial activities of the old organizations set up to reproduce the skilled labor input for Soviet industry, then the return to training may be lower than in the U.S., since these sectors are dying in Russia. Furthermore, as we discussed above, job training may represent part of the process of search in the presence of uncertainty concerning the value of alternative opportunities. In this case, some experiments may be unsuccessful in the sense of leading to little or no wage growth, (although they may still contribute to learning about the nature of the human capital revaluation which has occurred). This reasoning implies that we may observe increased variation of earnings for workers undertaking training, particularly when it involves acquisition of skills in a different field than the worker's current job.

To summarize, three sets of empirical hypotheses emerge from our discussion in of the nature of training in a restructuring economy. First, we 
hypothesize that the total amount of training may be higher or lower, relative to the level in a stable market economy, because of the opposing effects of return and risk. But we have emphasized the importance of distinguishing retraining for new skills from additional training in the same field: quantities of each type may be taken as proxies for the amounts of restructuring and inertia, respectively. Second, concerning training determinants, we hypothesize that the impact of prior human capital on training is lower in a restructuring than in a stable economy, and lower for retraining than for additional training. Organizational characteristics associated with restructuring should be associated with training. Firms with concentrated outside owners, especially foreign investors, engage in more training. Third, concerning outcomes of training, we hypothesize that retraining increases job, industry, and occupational mobility while additional training in the same field reduces mobility. Returns to training overall may be higher or lower than in a stable economy; they are likely to be higher for retraining, lower and perhaps negative for additional training in the same field, particularly when the field is declining. Finally, retraining is risky: the returns are highly variable, and retraining may sometimes lead to unemployment.

\section{DATA}

The data for this study are drawn from the Russian Longitudinal Monitoring Survey (RLMS), based on the first national probability sample drawn in the Russian Federation. The RLMS data consist of two longitudinal surveys of more than ten thousand individuals during 1992-1993 (Rounds 1-4) and 1994-1996, 1998 (Rounds 5-8). We employ data from the $5^{\text {th }}$ Round in 1994, the $6^{\text {th }}$ Round in 1995 , the $7^{\text {th }}$ Round in 1996 , and the $8^{\text {th }}$ Round in 1998. To focus on the implications of training for restructuring the existing labor force, as opposed to the somewhat different issues of educational reform and problems of new entrants, we restrict the sample in much of the analysis to individuals who were employed in 1994 . With respect to the determinants of 
training, our method is to relate the characteristics of workers and employers to the probability and amount of training between 1994 and 1998, based on retrospective questions on the 1998 survey pertaining to the previous three years. When examining the consequences of training, we take the 1998 outcomes, or the difference between the 1994 and 1998 outcomes, as our dependent variables.

The size of the adult sample (individuals answering the adult questionnaire, typically individuals age 14 and over) in 1994 is 8,893, in 1995 is 8,417 , in 1996 is 8,342 , and in 1998 is 8,701 . The number of adults in both the $1994 \& 1998$ rounds is 5,495. The number of adults employed in 1994 is 4,896, in 1998 is 4,250, and the number employed in both 1994 and 1998 is 2,419. ${ }^{1}$ The number of employed respondents in both years with non-missing values for the variables used in the training and mobility analyses is 2,333. The number of respondents with non-missing values of the variables used in the wage growth analysis is 2,054 . We also use a somewhat larger sample made up of the 3,068 individuals working in 1994, regardless of their employment status in 1998.

The panel structure of the RLMS permits us to examine changes in job characteristics of respondents who did and did not receive training (e.g. occupation, industry, firm and wages). Below we describe the construction of the variables used in the empirical analysis.

\section{Training Measures}

The training variables used in the analysis are constructed from a number of questions about participation in formal training programs that are asked in the RLMS. Although various types of informal skill acquisition, such as onthe-job learning, may represent quite important ways in which individuals enhance their skills and acquire new ones, we focus on formal training programs for measurement reasons. ${ }^{2}$ We include any training organized by firms, government, private agencies, and by workers themselves. 
The first training measure is additional training in the same field, which is based on the RLMS question:

"During the last 3 years were you or are you studying additional training courses in your current profession, field?"

The second is retraining, which is defined using the following RLMS question:

"During the last 3 years were you or are you studying courses where you studied some other profession, field, foreign language?"

These questions allow us, unlike previous studies, to examine the incidence of additional training and retraining, and to examine their effects on mobility and wage growth. We present training summary statistics from the 1995, 1996, and 1998 rounds of the panel below (no training questions were included in 1994, and no survey was conducted in 1997 or 1999), and for the distinction between additional training (in the same field as an individual is employed) and retraining (in other fields).

\section{Worker Characteristics}

We use a number of worker characteristics in our analysis of training, employment, mobility, and wage growth. We include in our models basic demographic characteristics such as gender, age, and years of schooling. These demographic characteristics along with years of tenure on the current job are available in each wave of the RLMS. After examining the answers to a set of open-ended questions on the individual survey questionnaires, we created a set of occupational codes using the International Labor Organization ISCO four-digit system. These codes are free of inconsistencies over time that are apparent in the original RLMS coding. These new codes are used to create occupation control variables at the one-digit level and to create a measure of occupational mobility. 


\section{Firm Characteristics}

Unfortunately, no information on industry of the firm employing the worker-respondent was included in the original, published data. Therefore, we created industry codes based on the Goskomstat 5-digit OKONH system after examining the answers to open-ended questions concerning the nature of the employer on each individual survey questionnaire. In the industrial sector, after identifying the enterprise, we assigned the industry code for that enterprise used by Goskomstat, as reported in the Registry of Industrial Firms. In the non-industrial sector, we assigned a code based on available information about the enterprise. These industry codes were used to create control variables (economic sectors of services, industry, and agriculture) and to create a measure of industrial mobility between 1994 and 1998.

In addition to industry, we created a set of dummy variables measuring ownership of the firm. For respondents working in industry we obtained ownership information from the Goskomstat Registry of Industrial Firms. We used the four Goskomstat categories of ownership: state, private, mixed (stateprivate), foreign. For respondents working in the non-industrial sector we followed two approaches. If there were several respondents working in the same firm, we measured ownership based on the majority opinion of the respondents or on the basis of a high-ranking individual within the firm. In this way, the ownership measure is consistent across all workers in the firm. If there was only one person working in the firm, we used that person's responses to questions about ownership.

The four categories of ownership (state, foreign, private, and mixed) are constructed using the following RLMS questions:

1. "Is the government the owner or co-owner of your enterprise?"

2. "Is your enterprise owned or co-owned by foreign firms or foreign individuals?"

3. "Is your enterprise owned or co-owned by Russian private individuals or Russian private firms?" 
Foreign firms are those for which the answer to question 2 is "yes." State firms are those for which the answer to question 1 is "yes," the answer to question 2 is "no," and the answer to question 3 is "no." Firms designated as (domestic) private are those for which the answer to question 1 is "no," the answer to question 2 is "no," and the answer to question 3 is "yes." Mixed firms are those for which the answer to question 1 is "yes," the answer to question 2 is "no," and the answer to question 3 is "yes."

Firm size is measured using the response to the RLMS question:

"How many people work in your enterprise?"

Because there are many missing values for this variable, we also created a firm size missing variable that is used in the analysis.

\section{Local Characteristics}

The share of workers employed in de novo firms is imputed for each RLMS district based on the RLMS question on the founding date of the enterprise. De novo firms are defined as firms founded between 1994 and 1998. This measure is used as a proxy for the local scale of job creation. The 1994 unemployment rate is taken from the regional yearbook and is determined using ILO methodology for each region in the Russian Federation. We expect to find a positive relationship between training and the share of workers employed in new firms. However, limited outside opportunities and a high unemployment rate probably reduce incentives to acquire additional training and retraining.

\section{Worker Mobility and Wage Growth}

Besides receipt of various types of training, the dependent variables in our analysis are worker mobility and wage growth. Worker mobility is measured in several ways. Using responses to the RLMS on the enterprise of the primary job, we construct a measure of interfirm mobility. Using the original RLMS survey responses, interfirm mobility is measured as a change in the enterprise of the primary job between 1994 and 1998. Occupational mobility is measured as a change in the newly created four-digit occupational 
code of the primary job between 1994 and 1998. Occupational mobility is further classified into interfirm occupational mobility, i.e., individuals who change occupations and firms, and intrafirm occupational mobility, i.e., individuals who change occupations but do not change firms. Industrial mobility is measured as a change in the five-digit industry code of the primary job between 1994 and 1998. These measures provide a comprehensive picture of the mobility of Russian workers. We also measure mobility using the transition among employment states between 1994 and 1998. In particular, starting with a sample of those working in firms in 1994, we observe whether each individual in 1998 was still employed in a firm, was self-employed, was unemployed, or was out of the labor force. Among the employed in 1998, the self-employed are individuals whose primary job was individual economic activity or who does not work at a firm or enterprise with more than one worker. The unemployed are those who did not have a job at the time of the 1998 interview, who had searched for a job in the previous 30 days and who reported themselves available to accept an appropriate job in the previous week. Those out of the labor force did not have a job at the time of the 1998 interview and had not searched in the previous 30 days or had searched but were not ready to accept an appropriate job in the previous week.

Wage growth is the difference in log of contractual wages for the primary and secondary jobs between 1994 and 1998. We needed to compute the contractual wage for both 1994 and 1998 for consistency because it was not available in the earlier RLMS rounds (1994-1996). Earlier RLMS questionnaires only asked actual earnings in previous month. Actual paid earnings is not an appropriate measure of the contractual wage given that 40$60 \%$ of Russian workers have wage arrears. Actual paid earnings are lower than the contractual wage when people did not get their wages in previous month and they are higher than the contractual wage when accumulated wage debt is paid. 
Following Earle and Sabirianova (2001), we have imputed the contractual wage in the following way. For workers with wage arrears, the contractual wage is the total wage debt on the primary and secondary jobs owed to the worker divided by the number of monthly wages owed. For workers without wage arrears the contractual wage is the actual monthly wage received last month from primary and secondary jobs. Wages are measured in nominal terms so we measure the log wage growth between 1994 and 1998 without controlling for inflation. However, since we have only one time period over which we are measuring wage growth, inflation between 1994 and 1998 is absorbed into the constant term of our log wage growth equation.

Table 1 contains the definitions of all of the variables used in the empirical analyses.

TABLE 1 ABOUT HERE

\section{RESULTS}

In this section, we report our analysis of the training activities of Russian workers over the period 1992-1998 using the Russian Longitudinal Monitoring Survey data. Table 2 shows the incidence of training in Russia by employment status using the 1995, 1996, and 1998 surveys of the RLMS. The overall incidence of training among Russian adults has fallen from $9.5 \%$ in the 1995 survey (covering the period 1992-95) to 8.9\% in the 1998 survey (covering the period 1995-98). Employees have the highest incidence of training in all three surveys, followed by the unemployed, the self-employed, and those out of the labor force. Receipt of additional training in the same field follows the same pattern across the four labor force status groups. On the other hand, the unemployed have the highest incidence rate for retraining in another field, while employees and the self employed have almost identical rates of retraining, followed by individuals out of the labor force. Given that 
they are already unemployed, it is less risky for individuals in that state to obtain training in another field. Those currently in jobs are less likely to risk obtaining training in another field and more likely to obtain additional training in their current field.

\section{TABLE 2 ABOUT HERE}

There is no clear pattern in changes in the incidence of overall training, additional training and retraining over time. While overall training incidence rates drop, the rates for the employment status groups follow a u-shape (employees, unemployed), increase (out of the labor force), or decrease (self employed). More important than any small changes over time is the overall finding that the incidence rates are very similar in magnitude across the three surveys. $^{3}$

The RLMS also asks respondents about the duration of retraining and additional training in number of calendar days. These are shown in Table 3. Again consistent patterns over time for the various labor force status groups are not observed. However, there do appear to be consistent regularities across groups at a point in time. In general, training durations are longer for the unemployed, especially in the case of retraining. Those who are actively seeking a new job spend the most time retraining, as might be expected. Training durations for those out of the labor force tend to be shorter than for the unemployed, while the average duration of training is shortest for employees.

\section{TABLE 3 ABOUT HERE}

Our modeling of the receipt of training and its effect on economic outcomes uses samples of workers in order to focus on job training and retraining issues that are central to restructuring from initial human capital acquisition decisions. As a starting point, Table 4 shows the incidence of formal training activities among Russian workers employed in 1994 and in both 1994 and 1998. Among those working in 1994, the training incidence rate between 1994 and 1998 is $11.93 \%$. For those working in both 1994 and 
1998, 13.93\% received some form of training between 1994 and 1998. The majority of reported training is training received in the worker's current field. A smaller proportion of workers received retraining in other fields.

\section{TABLE 4 ABOUT HERE}

For our regression analysis, we choose to report the results using the incidence measures of training rather than the duration measures in the statistical models that follow. While we have also estimated our receipt of training, mobility, and wage growth models using the duration training measures and obtained qualitatively similar results to those reported below, we are concerned with the problem of measurement error inherent in the RLMS duration measures. The RLMS questions only ask about calendar days of training, not about the average hours of training per day. Bartel and Sicherman (1998) noticed a similar reliability problem with the pre-1988 NLSY training duration measures. Barron, Berger, and Black (1997) find a greater correlation between firm and worker reports of formal training incidence than between firm and worker reports of the length of time it takes a worker to become fully trained in qualified, consistent with a greater potential measurement error problem with a length of time measure than with the incidence measure. ${ }^{4}$ Given this potential problem, we believe it is appropriate to focus on our analyses using the incidence measures of training.

How do the incidence estimates for Russia from the RLMS compare to the incidence of formal training activities in the United States? The U.S. Current Population Surveys (CPS) provide estimates of the incidence of training on both the previous and current job in 1983 and 1991. For 1983, Lillard and Tan (1992) report that $11.7 \%$ of men needed formal training on their previous job in order to obtain their current job, and $38.0 \%$ of men working at the time of the survey said that they had received training to improve their skills while on their current job. For 1991, Loewenstein and Spletzer (1999b) report a 44.1\% incidence rate of formal training among 16-64 year old workers while on their current job. However, an important weakness 
of the CPS training data is that the reference period is the entire current job, which varies from worker to worker.

On the other hand, the National Longitudinal Survey of Youth (NLSY) provides estimates of formal training incidence over fixed time periods but for a limited age range of workers. The individuals in the NLSY were aged 14-21 in 1979 at the beginning of the panel. Veum (1993) reports on the training received by individuals in the NLSY aged 21-29 in 1986 over the period from 1986 to 1991 . He finds $38.0 \%$ received some type of training to help find a job, learn new job skills, or learn a new job between 1986 and 1991. Training categories in his analysis included business school, vocational or technical institute, correspondence courses, formal company training, seminars outside of work, and other forms of training. Loewenstein and Spletzer (1999b) analyze the training data for the same cohort of individuals between 1993 and 1994. They find over that year $17.3 \%$ of workers had engaged in some type of formal training.

Thus, it appears that there is more formal training undertaken by workers in the United States than in Russia. However, comparisons are difficult because the NLSY samples are much younger than the RLMS samples (average age of 38.54 in 1994). In order to remove the age effects, we recalculated training incidence using the RLMS data for the same age ranges in the NLSY data. For 21-29 individuals in the RLMS, which matches the age range used by Veum (1993), the training incidence rate is $15.7 \%$. For the slightly older group of workers used by Loewenstein and Spletzer (1999b), the incidence rate in the RLMS is $13.9 \%$. These calculations make it apparent that the incidence rate of formal training in the RLMS data is substantially below that observed in the NLSY data for the same age groups. In fact, given the relatively small proportion of training activities in Russia devoted to retraining, the RLMS incidence rates most likely overstate the amount of useful training taking place. 
Table 5 shows the mean characteristics of workers in 1994 in the full RLMS sample of workers and the mean characteristics by receipt of training in subsequent years, where the sample includes individuals working in 1994 and observed (and responding to the training questions) in 1998. An interesting difference in the types of firms for which individuals work by the type of training received is that individuals receiving training in the same field are more likely to be working for state-owned firms than are individuals receiving retraining. In contrast, individuals receiving training in other fields are more likely to be working for private domestic, foreign, or mixed firms than are individuals receiving training in the same field.

\section{TABLE 5 ABOUT HERE}

Table 6 provides probit estimates of the receipt of training as a function of several worker and firm characteristics. The first column shows the model explaining the receipt of any kind of training between 1994 and 1998. The next two columns show the models explaining the receipt of additional training and retraining. In the first column, we see that training falls with age and tenure, increases with schooling, is more likely to be undertaken by managers, professionals and technicians, is less likely to be undertaken by workers in industry and agriculture as opposed to services, is less likely to be undertaken by workers in domestic private firms, and is more likely to be undertaken by workers in large firms. Regions with a higher share of employed in de novo firms and lower unemployment rates tend to have higher incidence of training.

TABLE 6 ABOUT HERE

The results in models for the two individual types of training tell us what factors are driving the overall results for the receipt of training. For example, older individuals are likely to get less of both types of training. The variable measuring previous years of schooling has a much larger impact on additional training in the same field than on retraining, suggesting that the substitutability between schooling and training increases with the extent of restructuring. This 
is also consistent with Bartel and Sicherman's (1998) argument concerning the impact of technological change on the schooling-training relationship. Thus, the results here support the complementarity hypothesis overall, while providing some evidence that schooling may increase the ability to deal with change, thus substituting to some extent for training. In addition, service workers are more likely to invest in retraining while technicians are more likely to receive additional training. Firm size is a more important determinant for the receipt of additional training in the same field than it is for the retraining.

We can compare our results on the determinants of the incidence of formal training in the RLMS with those for the United States reported by Loewenstein and Spletzer (1999b) using the 1993-94 NLSY data and by Veum (1995) using the 1990 NLSY data. Like the RLMS results, both Loewenstein and Spletzer (1999b) and Veum (1995) report that higher education levels are associated with higher probability of the receipt of training. Loewenstein and Spletzer (1999b) and Veum (1995) both find that larger firms are more likely to provide training (except for outside seminars), consistent with the RLMS results for the provision of training in the same field. The RLMS estimates suggest a flat tenure profile for the probability of receiving training (this is also the case when a quadratic tenure specification is employed). In contrast, Bartel and Sicherman (1998), Loewenstein and Spletzer (1999b), and Veum (1997) find fairly strong evidence that the probability of the receipt of formal training increases with tenure, although at a decreasing rate. ${ }^{5}$

Turning to the effects of training, we first consider worker mobility of several types: across industries, firms, occupations, and labor force states, and within firms. Table 7 shows the proportion of all workers that experienced mobility between 1994 and 1998, along with mobility experiences of those workers that have received some form of training in that period. The mobility rates of those receiving retraining in other fields appear higher than the 
mobility rates of the typical worker. On the other hand, the mobility rates of those receiving training in the same field appear to be lower than those of the typical worker.

\section{TABLE 7 ABOUT HERE}

Table 8 shows probit estimates explaining interindustry, interfirm mobility, and occupational mobility as a function of a number of worker and firm characteristics, including the receipt of training between 1994 and 1998. We focus on the results for the training variables. Additional training in the same field appears to reduce all types of mobility, while retraining appears to raise mobility. The results for additional training in the same field are consistent with those using NLSY data in the United States that the receipt of training is associated with lower mobility (e.g. Loewenstein and Spletzer 1997, 1999a; Parent, 1999). Retraining works in exactly the opposite direction, providing further support that the distinction between types of training is an important one. This type of training appears to facilitate worker mobility and is more likely to be the result of workers' adjustments to transition and restructuring than is additional training in the same field.

\section{TABLE 8 ABOUT HERE}

Finally, we note that the insignificant coefficients on years of schooling in each of the equations is slightly puzzling in light of the argument that schooling enhances the ability to deal with change. However, in some cases schooling may be more like an investment in occupation-specific skills. In these cases additional schooling may reduce the propensity to mobility, especially occupational mobility within and across firms, leading to the observation of insignificant effects in the mobility equations.

In Table 9, we estimate the effect of training on employment transitions between 1994 and 1998. We estimate a multinomial logit model in which the employed in 1994 either transition to self-employment, unemployment, out of the labor force, or remain employed in an enterprise in 1998. $74.5 \%$ of the sample remains employed in an enterprise in $1998,4.6 \%$ 
transitions to self-employment, $5.2 \%$ transitions to unemployment, and $15.7 \%$ transitions to out of the labor force in 1998. The reference category in Table 9 is remaining employed in an enterprise in 1998. This transition is a function of training and other observable firm and worker characteristics in 1994 . We find that additional training in the same field reduces the probability of transiting from employment to self-employment, unemployment or out of the labor force relative to staying employed. Thus, additional training in the same field is associated with lower levels of mobility into any other employment state. In contrast, retraining only raises the probability of transiting to unemployment relative to remaining employed. While retraining may help mobility to a different industry or occupation, as we saw in Table 7, Table 8 also shows that there is some risk involved: it also raises the chances of being unemployed. Such unemployment may reflect training failures or it may represent productive search that is complementary with the new skills, but in either case the finding is consistent with our view of such retraining as involving search and experimentation in the presence of uncertainty.

\section{TABLE 9 ABOUT HERE}

In Table 10 we examine the relationship between training and wage growth. In the U.S., the typical finding is that training leads to increases in wage growth (e.g., Veum, 1995; Barron, Berger and Black, 1999; Loewenstein and Spletzer, 1999b), consistent with what one would expect from a standard human capital model. In Panel A, we show the average growth in nominal log wages between 1994 and 1998 for all workers and workers receiving the two different types of training. Across the entire sample, nominal log wages increase by 1.291 or $264 \%$ (calculated as $\exp (1.291)-1$ ). At the same time, prices in Russia increased by 476\% (CPI in December $1994=43.234$ (December 1995=100); CPI in December $1998=249.305$ ). So real wages of these workers declined substantially from 1994 to 1998 . The average wage growth of those obtaining any training between 1994 and 1998 is slightly higher than the wage growth of the typical worker. However, this comparison 
is misleading in that it lumps together additional training in the same field and retraining, which have radically different effects on wage growth. Workers receiving retraining in another field have substantially higher wage growth than the typical worker, while the average wage growth of workers receiving the additional training in the same field look is slightly lower than the wage growth of the typical worker. This provides some initial evidence that types of training associated with labor reallocation and acquisition of new skills may be more productive in a transition economy such as Russia's than training that merely enhances an existing skill set. Also note that the standard deviation of wages is higher for workers retraining than for additional training, consistent with our hypothesis that the revaluation of skills led to significant uncertainty about the returns to retraining of various types, thus that retraining involves a process of search.

\section{TABLE 10 ABOUT HERE}

In Panel B, log wage growth between 1994 and 1998 is regressed on the log change in hours of work, a number of worker and firm characteristics observed in 1994, and whether workers have received training between 1994 and 1998. In the first column, we see that the dummy variable for either type of training in insignificantly related to wage growth. This result again masks the different effects of additional training and retraining. When the two separate types of training are included in the wage growth equation in the second column, the same pattern we saw in Panel A emerges. Consistent with theory, retraining raises wage growth. Additional training in the same field is associated with lower wage growth, even though as we saw earlier that it was associated with more employment stability. These results suggest that the training most likely to be associated with restructuring, retraining in other fields, has the highest return. Training most likely to be coming from leftover programs from the pre-transition era, additional training in the same field, is less likely to be imparting skills valuable in a market economy and actually yields negative returns. ${ }^{6}$ 
The returns obtained from retraining in other fields are substantially larger than those observed for training investments over similar periods in the United States. According to the estimates in Table 10, retraining increases log wages between 1994 and 1998 by .304 or 35.5\% (calculated as $\operatorname{exp(.304)-1).~}{ }^{7}$ Barron, Berger, and Black (1999) calculate elasticities of wage growth over a two year period with respect to training using the 1982 EOPP and 1992 SBA data. These elasticities are .028 and .020 respectively. While these seem fairly low compared to the Russian results, they cannot be directly compared because the training is measured in terms of hours rather than a dummy variable for the receipt of training. Better comparisons can be obtained using the NLSY results of Veum (1995) and Loewenstein and Spletzer (1999b). Using dummy variables for the reciept of training and controlling for a number of other characteristics, Veum (1995) finds that company provided formal training increases log wages between 1986 and 1990 by .0897 or $9.38 \%$ and that seminars outside of work increase log wages by .0848 or $8.85 \%$. Similarly, Loewenstein and Spletzer (1999b) find that after controlling for several characteristics, receipt of formal training increases log wages between 1993 and 1994 by .0328 or $3.33 \%$ across jobs and up to .0452 or $4.62 \%$ within jobs. These are much smaller estimated effects than those estimated for retraining in using the RLMS data between 1994 and 1998. The difference is even more impressive when we consider that the NLSY sample is much younger (e.g. ages 21-29 in 1986) with presumably steeper earnings profiles and possibly more intensive training activities than the older RLMS sample (average age $=38.47$ in 1994). 


\section{CONCLUSIONS}

Most of the research on private-sector training decisions by workers and firms has ignored issues of structural change and demand shifts. Perhaps because Western economies tend to be relatively stable, or perhaps because of economists' predilection for analyzing static equilibria, the focus has rather been on training patterns over the worker and job life-cycles. A notable exception is Bartel and Sicherman's (1998) analysis of the impact of technological change on the incidence of training and on the training gap between high and low-educated workers. In their analysis, technological change is treated as a continuous process, with a constant rate over time and varying only across industries. By contrast, the restructuring situation is more akin to a one-time shock of dramatic structural change and sudden shifts in the demand for different types of human capital.

This paper has made a first attempt to measure the causes and consequences of worker training in this restructuring environment. We have argued that transition economies in general, and Russia in particular, represent a fruitful setting to investigate this question, given the suddenness and magnitude of the shocks from liberalization and opening to the world economy.

We have hypothesized that the restructuring process, relative to the situation in a stable market economy, has ambiguous effects on the incidence of training. On the one hand, the need for labor reallocation would appear to promote training, particularly retraining of the "job-switching" type that provides new skills for new types of work. On the other hand, the increased uncertainty associated with the shift in the earnings structure suggests that workers and firms may be reluctant to undertake training investments. The possibility that formal schooling and training tend to be more substitutable in a restructuring context led us to conjecture that the correlation of the previous years of schooling and the training variables might be attenuated, similar to Bartel and Sicherman's (1998) argument concerning the impact of 
technological change. The role of firms in training their workers and the problems of corporate governance in the transition environment led us to hypothesize that training might be higher in privately owned companies, particularly those dominated by foreign investors. We also hypothesized that restructuring would tend to increase the covariance of training with mobility, as workers retrain for new types of work, and perhaps with wages, as the initial disequilibrium created by the transition shocks permits short-run rents to be gathered by the first movers to new fields.

Drawing upon household panel data for Russia, we have examined evidence concerning these hypotheses. Our findings suggest that that the incidence of formal training by Russian workers is below that observed for workers in the United States during roughly the same time period. We put forth the interpretation that uncertainty associated with the revaluation of skills may be outweighing the potential returns to training in a restructuring environment. Our analysis goes on to provide evidence for this interpretation in several ways. Retraining in other fields is estimated to have strongly positive effects on labor mobility and on wage growth, which supports our contention that such training has substantial potential returns, but it also raises wage variability and the probability of a transition to unemployment, implying there may be significant risks. The negative returns to additional training in the current field are consistent with the view that such training represents the inertia of the old system of training institutions. These training programs may be offering skills that might have been useful during the Soviet era but have ceased to be so in a restructuring economy.

The results thus suggest a fairly coherent picture of training in Russia. But they also provide some broader lessons for the analysis of training. We have demonstrated the importance of distinguishing retraining in new skills from additional training in the current field. Our analysis shows substantial differences in behavior related to the two types of training, both in the process determining the decision to undertake the training and in the consequences for 
mobility and earnings. One may very well get similar results for additional training and retraining on mobility and earnings using Western data. While it is unlikely that additional training would have negative returns in most Western economies, it is not unreasonable to expect that the returns to retraining would exceed those from additional training in the same field. If so, our results would indicate the importance of retraining more generally outside the restructuring context. 


\section{REFERENCES}

Barron, J. M., Berger, M. C., and Black, D. A. (1999). Do Workers Pay for On-the-Job Training? Journal of Human Resources, 34 (Spring), 235-252.

Barron, J. M., Berger, M. C., and Black D. A. (1997). On-the-Job Training. Kalamazoo, MI. Upjohn Institute for Employment Research.

Bartel, A. P. and Sicherman N. (1998). Technological Change and the Skill Acquisition of Young Workers. Journal of Labor Economics, 16 (October), 718-755.

Bartel, A. P. and Sicherman, N. (1999). Technological Change and Wages: An Inter-Industry Analysis. Journal of Political Economy, 107 (April), 285-325.

Boeri, T., and Flinn, C. J. (1999). Returns to Mobility in the Transition to a Market Economy. Journal of Comparative Economics, 27 (March), 4-32.

Earle, J. S., and Pauna, C. (1998). Long-Term Unemployment, Social Assistance and Labor Market Policies in Romania. Empirical Economics, $23(1-2), 203-35$.

Earle, J. S., and Sabirianova K. (2001). How Late to Pay? Understanding Wage Arrears in Russia. Forthcoming in Journal of Labor Economics.

Felstead, A., Green F., Mayhew K., and Pack A. (1999). The Impact of Training on Labor Mobility. Centre for Labour Market Studies, University of Leicester, September.

Kluve, J., Lehmann, H. and Schmidt C. M. (1999). Active Labor Market Policies in Poland: Human Capital Enhancement, Stigmatization, or Benefit Churning? Journal of Comparative Economics, 27 (March), 61-89. 
Lechner, M. (2000). An Evaluation of Public-Sector-Sponsored Continuous Vocational Training Programs in East Germany. Journal of Human Resources, 35 (Spring), 347-375.

Lillard, L. A. and Tan, H. W. (1992). Private Sector Training: Who Gets it and What are its Effects? Research in Labor Economics, 13, 1-62.

Loewenstein, M. A. and Spletzer, J. R. (1997). Delayed Formal On-the-Job Training. Industrial and Labor Relations Review, 51 (October), 82-99.

Loewenstein, M. A. and Spletzer, J. R. (1999a). General and Specific Training. Journal of Human Resources, 34 (Fall), 710-733.

Loewenstein, M. A. and Spletzer, J. R. (1999b). Formal and Informal Training: Evidence from the NLSY. Research in Labor Economics, 18, 403438.

Lubyova, M., and van Ours J. C. (1999). Effects of Active Labor Market Programs on the Transition Rate from Unemployment into Regular Jobs in the Slovak Republic. Journal of Comparative Economics, 27 (March), 90-112.

Lynch, L. M. and Black S. E. (1998). Beyond the Incidence of EmployerProvided Training. Industrial and Labor Relations Review, 52 (October), 6481.

Lynch, L. M. (1992). Private Sector Training and the Earnings of Young Workers. American Economic Review, 82 March, 299-312.

Mincer, J. (1962). On the Job Training: Costs, Returns, and Some Implications. Journal of Political Economy, 70 (October, pt. 2), 50-79.

O’Leary, C. J. (1997). A Net Impact of Active Labour Programmes in Hungary. Economics of Transition, 5(2), 453-484. 
O'Leary, C. J., Kolodziejczyk, P., and Lazar, G. (1998). “The Net Impact of Labour Programmes in Hungary and Poland. International Labour Review, 137(3), 321-346.

Orazem, P. F. and Vodopivec, M. (1997). Value of Human Capital in Transition to Market: Evidence from Slovenia. European Economic Review, 41 (April), 893-903.

Parent, D. (1999). Wages and Mobility: The Impact of Employer-Provided Training. Journal of Labor Economics, 17 (April), 298-317.

Terrell, K., and Sorm, V. (1999). Labor Market Policies and Unemployment in the Czech Republic. Journal of Comparative Economics, 27 (March), 33-60.

Veum, J. R. (1995). Sources of Training and Their Impact on Wages. Industrial and Labor Relations Review, 48 (July), 812-826.

Veum, J. R. (1993). Training Among Young Adults: Who, What Kind, and for How Long. Monthly Labor Review, 116 (August), 27-32.

Veum, J. R. (1997). Training and Job Mobility among Young Workers in the United States. Journal of Population Economics, 10 (May), 219-233. 
Table 1. Variable Definitions

\begin{tabular}{|c|c|c|}
\hline & Variable Name & Variable Definition \\
\hline \multirow{6}{*}{ 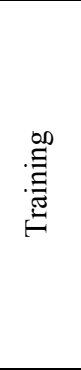 } & Receipt of Training & $=1$ if received training in last three years \\
\hline & $\begin{array}{l}\text { Receipt of Additional } \\
\text { Training }\end{array}$ & $\begin{array}{l}=1 \text { if received additional training in current profession or field in } \\
\text { the last three years }\end{array}$ \\
\hline & Receipt of Retraining & $\begin{array}{l}=1 \text { if received training in another profession or field in the last three } \\
\text { years }\end{array}$ \\
\hline & Duration of Training & Number of calendar days of training in the last three years \\
\hline & $\begin{array}{l}\text { Duration of Additional } \\
\text { Training }\end{array}$ & $\begin{array}{l}\text { Number of calendar days of additional training in current profession } \\
\text { or field in the last three years }\end{array}$ \\
\hline & Duration of Retraining & $\begin{array}{l}\text { Number of calendar days of additional training in another } \\
\text { profession or field in the last three years }\end{array}$ \\
\hline \multirow{4}{*}{ 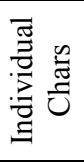 } & Female & $=1$ if female \\
\hline & Age & Age in years, 1994 \\
\hline & Schooling & Years of schooling completed, 1994 \\
\hline & Tenure & Years of tenure in current job, 1994 \\
\hline 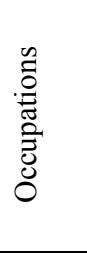 & $\begin{array}{l}\text { Managers and Professionals } \\
\text { Technicians } \\
\text { Clerks } \\
\text { Service Workers } \\
\text { Craft Workers } \\
\text { Operators and Assemblers } \\
\text { Unskilled Workers }\end{array}$ & $\begin{array}{l}=1 \text { if } 1994 \text { primary occupation is manager or professional } \\
=1 \text { if } 1994 \text { primary occupation is technician } \\
=1 \text { if } 1994 \text { primary occupation is clerk } \\
=1 \text { if } 1994 \text { primary occupation is service worker } \\
=1 \text { if } 1994 \text { primary occupation is craft worker } \\
=1 \text { if } 1994 \text { primary occupation is operator or assembler } \\
=1 \text { if } 1994 \text { primary occupation is unskilled worker }\end{array}$ \\
\hline $\begin{array}{l}n \\
\tilde{0} \\
\tilde{U} \\
\tilde{n} \\
\tilde{n}\end{array}$ & $\begin{array}{l}\text { Industry } \\
\text { Agriculture } \\
\text { Services }\end{array}$ & $\begin{array}{l}=1 \text { if } 1994 \text { primary employer is in industry } \\
=1 \text { if } 1994 \text { primary employer is in agriculture } \\
=1 \text { if } 1994 \text { primary employer is in services }\end{array}$ \\
\hline 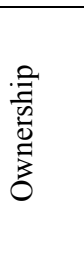 & $\begin{array}{l}\text { State } \\
\text { Domestic Private } \\
\text { Mixed } \\
\text { Foreign }\end{array}$ & $\begin{array}{l}=1 \text { if } 1994 \text { primary employer is owned or co-owned by state } \\
=1 \text { if } 1994 \text { primary employer is owned or co-owned by Russian } \\
\text { private individuals or Russian firms } \\
=1 \text { if } 1994 \text { primary employer is co-owned by state and foreign firms } \\
\text { or individuals } \\
=1 \text { if } 1994 \text { primary employer is owned or co-owned by foreign } \\
\text { firms or foreign individuals }\end{array}$ \\
\hline$\stackrel{\tilde{N}}{i s}$ & $\begin{array}{l}\text { Firm Size (,000 employed) } \\
\text { Firm Size Missing }\end{array}$ & $\begin{array}{l}\text { Thousands of persons working at enterprise of primary job } \\
=1 \text { if number of persons working at enterprise missing }\end{array}$ \\
\hline $\begin{array}{l}\widetilde{J} \\
\stackrel{\Xi}{0} \\
\end{array}$ & $\begin{array}{l}\text { Share of Employed in De } \\
\text { Novo Firms } \\
1994 \text { Unemployment Rate }\end{array}$ & $\begin{array}{l}\text { Share of employment by RLMS district accounted for by firms } \\
\text { created between } 1994 \text { and } 1998 \\
1994 \text { regional unemployment rate }\end{array}$ \\
\hline \multirow{3}{*}{ 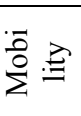 } & Interindustry Mobility & $=1$ if 5 -digit industry code of primary job changed 1994 to 1998 \\
\hline & Interfirm Mobility & $=1$ if enterprise of primary job changed 1994 to 1998 \\
\hline & Occupational Mobility & $=1$ if 4-digit occupation code of primary job changed 1994-1998 \\
\hline \multirow{4}{*}{ 密壳 } & Employed & $=1$ if currently employed in an enterprise \\
\hline & Self-employed & $=1$ if currently self-employed \\
\hline & Unemployed & $=1$ if currently unemployed \\
\hline & Out-of-Labor Force & $=1$ if out-of-labor force \\
\hline \multirow{3}{*}{ 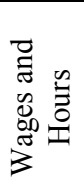 } & Nominal Wage Growth & $\begin{array}{l}\text { Log(monthly contractual wage, primary and secondary jobs, 1998)- } \\
\text { Log (monthly contractual wage, primary and secondary jobs 1994) }\end{array}$ \\
\hline & $\begin{array}{l}\text { Growth Rate of Hours } \\
\text { Worked }\end{array}$ & $\begin{array}{l}\text { Log (hours worked in previous month, 1998) - Log (hours worked } \\
\text { in previous month, 1994) }\end{array}$ \\
\hline & Hours Worked Missing & $=1$ if hours worked missing in either 1998 or 1994 \\
\hline
\end{tabular}


Table 2. Incidence of Training in Russia by Employment Status, 1995, 1996, and 1998

\begin{tabular}{|l|c|c|c|c|}
\hline & $\begin{array}{c}\text { Receipt of } \\
\text { Any Type of } \\
\text { Training }\end{array}$ & $\begin{array}{c}\text { Receipt of } \\
\text { Additional } \\
\text { Training }\end{array}$ & $\begin{array}{c}\text { Receipt of } \\
\text { Retraining }\end{array}$ & N \\
\hline 1995 Survey & 0.145 & 0.112 & 0.046 & 4425 \\
Employees & 0.084 & 0.036 & 0.052 & 443 \\
Self-employed & 0.111 & 0.049 & 0.071 & 406 \\
Unemployed & 0.024 & 0.006 & 0.019 & 3085 \\
Out-of-Labor Force & 0.095 & 0.066 & 0.038 & 8375 \\
Total & & & & \\
1996 Survey & 0.141 & 0.108 & 0.045 & 4230 \\
Employees & 0.081 & 0.042 & 0.044 & 406 \\
Self-employed & 0.083 & 0.023 & 0.066 & 470 \\
Unemployed & 0.027 & 0.006 & 0.022 & 3183 \\
Out-of-Labor Force & 0.091 & 0.061 & 0.037 & 8308 \\
Total & & & & \\
1998 Survey & & & & \\
Employees & 0.144 & 0.120 & 0.040 & 4012 \\
Self-employed & 0.078 & 0.043 & 0.041 & 579 \\
Unemployed & 0.095 & 0.037 & 0.065 & 507 \\
Out-of-Labor Force & 0.028 & 0.006 & 0.023 & 3553 \\
Total & 0.089 & 0.063 & 0.035 & 8670 \\
\hline
\end{tabular}

Source: Authors' estimates from the Russian Longitudinal Monitoring Surveys. 
Table 3. Average Duration of Training per Trainee, Days

\begin{tabular}{|l|c|c|r|}
\hline & $\begin{array}{c}\text { Duration of Any } \\
\text { Type of Training } \\
\text { per Trainee }\end{array}$ & $\begin{array}{c}\text { Duration of } \\
\text { Additional } \\
\text { Training per } \\
\text { Trainee }\end{array}$ & $\begin{array}{c}\text { Duration of } \\
\text { Retraining } \\
\text { per Trainee }\end{array}$ \\
\hline 1995 Survey & 69.0 & 50.9 & 93.1 \\
Employees & 88.2 & 59.5 & 100.4 \\
Self-employed & 119.4 & 79.8 & 134.6 \\
Unemployed & 114.8 & 109.6 & 103.1 \\
Out-of-Labor Force & 76.0 & 54.1 & 100.0 \\
Total & & & \\
1996 Survey & 69.6 & 55.2 & 86.5 \\
Employees & 131.7 & 116.3 & 121.1 \\
Self-employed & 116.1 & 64.2 & 123.7 \\
Unemployed & 113.2 & 100.1 & 98.6 \\
Out-of-Labor Force & 78.8 & 58.5 & \\
Total & & & 77.0 \\
1998 Survey & 54.4 & 40.8 & 82.5 \\
Employees & 94.5 & 90.4 & 140.7 \\
Self-employed & 136.3 & 97.6 & 125.0 \\
Unemployed & 117.8 & 75.4 & 96.2 \\
Out-of-Labor Force & 68.5 & 45.9 & \\
Total & & & \\
\hline
\end{tabular}

Source: Authors' estimates from the Russian Longitudinal Monitoring Surveys. 
Table 4. Incidence of Training among Russian Workers between 1994 and 1998

\begin{tabular}{|l|c|c|}
\hline Incidence of Training & $\begin{array}{c}\text { Proportion of } \\
\text { Respondents } \\
\text { Employed in 1994 } \\
\text { Receiving Training }\end{array}$ & $\begin{array}{c}\text { Proportion of } \\
\text { Respondents } \\
\text { Employed in 1994 } \\
\text { and 1998 Receiving } \\
\text { Training }\end{array}$ \\
Any Type of Training & .1193 & .1393 \\
Additional Training (in the same & .0988 & .1200 \\
field) & & \\
Retraining (in other fields) & .0329 & .0334 \\
N & {$[3,068]$} & {$[2,333]$} \\
\hline $\begin{array}{l}\text { Average Duration of Training per } \\
\text { Trainee (Days) }\end{array}$ & & \\
Any Type of Training & 50.65 & {$[319]$} \\
N & {$[356]$} & 34.91 \\
Additional Training (in the same & 37.48 & {$[277]$} \\
field) & {$[299]$} & \\
N & & 69.83 \\
Retraining (in other fields) & 72.02 & {$[76]$} \\
N & {$[96]$} & \\
\hline Sor & & \\
\hline
\end{tabular}

Source: Authors' estimates from the Russian Longitudinal Monitoring Surveys. 
Table 5. 1994 Characteristics of Russian Workers, by Receipt of Training from 1994 to 1998

\begin{tabular}{|c|c|c|c|c|}
\hline & & $\begin{array}{c}\text { All } \\
\text { Respondents } \\
\text { Employed in } \\
1994 \text { and } 1998\end{array}$ & $\begin{array}{c}\text { Received } \\
\text { Additional } \\
\text { Training }\end{array}$ & $\begin{array}{l}\text { Received } \\
\text { Retraining }\end{array}$ \\
\hline \multirow{6}{*}{ 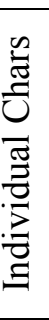 } & Female & 0.536 & 0.671 & 0.667 \\
\hline & Age (years) & 38.466 & 37.675 & 33.808 \\
\hline & & $(10.329)$ & $(10.108)$ & $(10.370)$ \\
\hline & Schooling (years) & 11.932 & 13.466 & 12.801 \\
\hline & & $(2.484)$ & (2.034) & $(2.218)$ \\
\hline & Tenure (years) & $\begin{array}{c}9.055 \\
(8.693)\end{array}$ & $\begin{array}{c}8.657 \\
(8.354)\end{array}$ & $\begin{array}{l}7.136 \\
(8.504)\end{array}$ \\
\hline \multirow{8}{*}{ 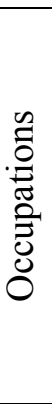 } & Managers and & 0.207 & 0.432 & 0.308 \\
\hline & Professionals & & & \\
\hline & Technicians & 0.169 & 0.293 & 0.218 \\
\hline & Clerks & 0.074 & 0.054 & 0.077 \\
\hline & Service Workers & 0.078 & 0.036 & 0.141 \\
\hline & Craft Workers & 0.182 & 0.075 & 0.077 \\
\hline & Operators and & 0.196 & 0.086 & 0.141 \\
\hline & $\begin{array}{l}\text { Assemblers } \\
\text { Unskilled Workers }\end{array}$ & 0.094 & 0.025 & 0.038 \\
\hline \multirow{3}{*}{ 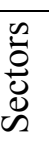 } & Industry & 0.290 & 0.175 & 0.321 \\
\hline & Agriculture & 0.139 & 0.032 & 0.051 \\
\hline & Services & 0.571 & 0.793 & 0.628 \\
\hline \multirow{4}{*}{ है } & State & 0.525 & 0.739 & 0.577 \\
\hline & Domestic Private & 0.143 & 0.061 & 0.115 \\
\hline & Mixed & 0.319 & 0.186 & 0.282 \\
\hline & Foreign & 0.013 & 0.014 & 0.026 \\
\hline \multirow{3}{*}{$\stackrel{\mathscr{N}}{\mathscr{N}}$} & Firm Size $(, 000$ & 2.166 & 4.820 & 1.563 \\
\hline & employed) & $(15.707)$ & $(27.832)$ & $(5.363)$ \\
\hline & Firm Size Missing & 0.190 & 0.164 & 0.154 \\
\hline \multirow{4}{*}{ 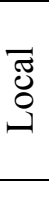 } & Share of Employed in & 0.158 & 0.168 & 0.185 \\
\hline & De Novo Firms & $(0.081)$ & $(0.079)$ & $(0.066)$ \\
\hline & $\begin{array}{l}1994 \text { Unemployment } \\
\text { Rate }\end{array}$ & $\begin{array}{l}7.646 \\
(1.665)\end{array}$ & $\begin{array}{c}7.457 \\
(1.421)\end{array}$ & $\begin{array}{c}7.437 \\
(1.348)\end{array}$ \\
\hline & $\mathrm{N}$ & 2,333 & 280 & 78 \\
\hline
\end{tabular}

Note: Standard deviations are in parentheses. Sample consists of respondents employed in 1994 and 1998. Source: Authors' estimates from the Russian Longitudinal Monitoring Surveys. 
Table 6. Determinants of Receipt of Training 1994-1998, Probit Estimates

\begin{tabular}{|c|c|c|c|c|}
\hline & & $\begin{array}{l}\text { Receipt of any } \\
\text { Type of Training }\end{array}$ & $\begin{array}{c}\text { Receipt of } \\
\text { Additional } \\
\text { Training }\end{array}$ & $\begin{array}{l}\text { Receipt of } \\
\text { Retraining }\end{array}$ \\
\hline 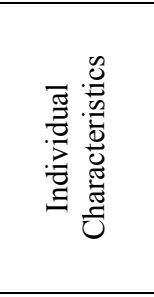 & $\begin{array}{l}\text { Female } \\
\text { Age (years) } \\
\text { Schooling (years) } \\
\text { Tenure (years) }\end{array}$ & $\begin{array}{c}0.011 \\
(0.784) \\
-0.002 * * * \\
(-3.009) \\
0.015^{* * *} \\
(3.901) \\
-0.001 \\
(-1.199) \\
\end{array}$ & $\begin{array}{c}0.016 \\
(1.275) \\
-0.001 * * \\
(-2.127) \\
0.014 * * * \\
(3.962) \\
-0.001 \\
(-1.255) \\
\end{array}$ & $\begin{array}{c}0.004 \\
(0.608) \\
-0.001 * * * \\
(-4.171) \\
0.002 \\
(1.280) \\
0.000 \\
(0.221) \\
\end{array}$ \\
\hline 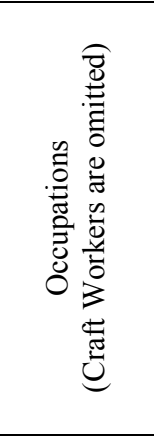 & $\begin{array}{l}\text { Managers and Professionals } \\
\text { Technicians } \\
\text { Clerks } \\
\text { Service Workers } \\
\text { Operators and Assemblers } \\
\text { Unskilled Workers }\end{array}$ & $\begin{array}{c}0.091 * * * \\
(3.374) \\
0.091 * * * \\
(3.650) \\
0.022 \\
(0.678) \\
-0.005 \\
(-0.149) \\
0.022 \\
(0.883) \\
-0.027 \\
(-0.752) \\
\end{array}$ & $\begin{array}{c}0.069 * * * \\
(2.958) \\
0.068 * * * \\
(3.127) \\
0.008 \\
(0.292) \\
-0.040 \\
(-1.299) \\
0.010 \\
(0.429) \\
-0.040 \\
(-1.245)\end{array}$ & $\begin{array}{c}0.026^{* *} \\
(1.992) \\
0.020 \\
(1.626) \\
0.017 \\
(1.233) \\
0.033^{* *} \\
(2.521) \\
0.016 \\
(1.418) \\
0.009 \\
(0.526) \\
\end{array}$ \\
\hline 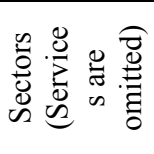 & $\begin{array}{l}\text { Industry } \\
\text { Agriculture }\end{array}$ & $\begin{array}{l}-0.030^{*} \\
(-1.693) \\
-0.095^{* * *} \\
(-3.528)\end{array}$ & $\begin{array}{l}-0.033 * * \\
(-2.110) \\
-0.086^{* * *} \\
(-3.435)\end{array}$ & $\begin{array}{l}0.014^{*} \\
(1.785) \\
-0.010 \\
(-0.788)\end{array}$ \\
\hline 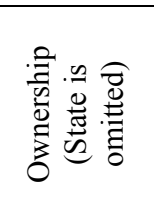 & $\begin{array}{l}\text { Domestic Private } \\
\text { Mixed } \\
\text { Foreign }\end{array}$ & $\begin{array}{l}-0.089 * * * \\
(-4.012) \\
-0.031 * \\
(-1.844) \\
-0.012 \\
(-0.223)\end{array}$ & $\begin{array}{c}-0.087 * * * \\
(-4.196) \\
-0.032 * * \\
(-2.231) \\
0.013 \\
(0.285)\end{array}$ & $\begin{array}{c}-0.015 \\
(-1.532) \\
-0.005 \\
(-0.565) \\
0.004 \\
(0.194)\end{array}$ \\
\hline$\stackrel{\tilde{N}}{\omega}$ & $\begin{array}{l}\text { Firm Size (,000 employed) } \\
\text { Firm Size Missing Dummy }\end{array}$ & $\begin{array}{c}0.001^{*} \\
(1.847 \\
-0.023 \\
(-1.389)\end{array}$ & $\begin{array}{l}0.001 * * \\
(1.976) \\
-0.010 \\
(-0.661)\end{array}$ & $\begin{array}{l}-0.000 \\
(-0.789) \\
-0.011 \\
(-1.470)\end{array}$ \\
\hline 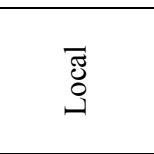 & $\begin{array}{l}\text { Share of Employed in De } \\
\text { Novo Firms } \\
1994 \text { Unemployment Rate }\end{array}$ & $\begin{array}{l}0.253 * * * \\
(3.341) \\
-0.009 * * \\
(-2.442)\end{array}$ & $\begin{array}{l}0.137 * * \\
(2.031) \\
-0.007 * * \\
(-2.081)\end{array}$ & $\begin{array}{l}0.120^{* * *} \\
(3.960) \\
-0.004^{*} \\
(-1.954)\end{array}$ \\
\hline & Intercept & $\begin{array}{l}-0.271 * * * \\
(-4.229)\end{array}$ & $\begin{array}{l}-0.252 * * * \\
(-4.436)\end{array}$ & $\begin{array}{l}-0.086^{* * * *} \\
(-2.693)\end{array}$ \\
\hline & $\begin{array}{l}\text { LR chi2(19) } \\
\text { Pseudo } \mathrm{R}^{2}\end{array}$ & $\begin{array}{c}255.37 \\
0.138\end{array}$ & $\begin{array}{c}252.60 \\
0.151\end{array}$ & $\begin{array}{l}66.07 \\
0.087\end{array}$ \\
\hline
\end{tabular}

Note: $* * *$ - significant at the $1 \%$ level, $* *$ - significant at the $5 \%$ level; *-significant at the $10 \%$ level; tstatistics are in parentheses; t-statistics are defined with robust standard errors. Sample consists of respondents employed in 1994 and 1998. $\mathrm{N}=2,333$. The explanatory variables are measured in 1994 . Coefficients show the marginal effect $\mathrm{dF} / \mathrm{dX}$.

Source: Authors' estimates from the Russian Longitudinal Monitoring Surveys. 


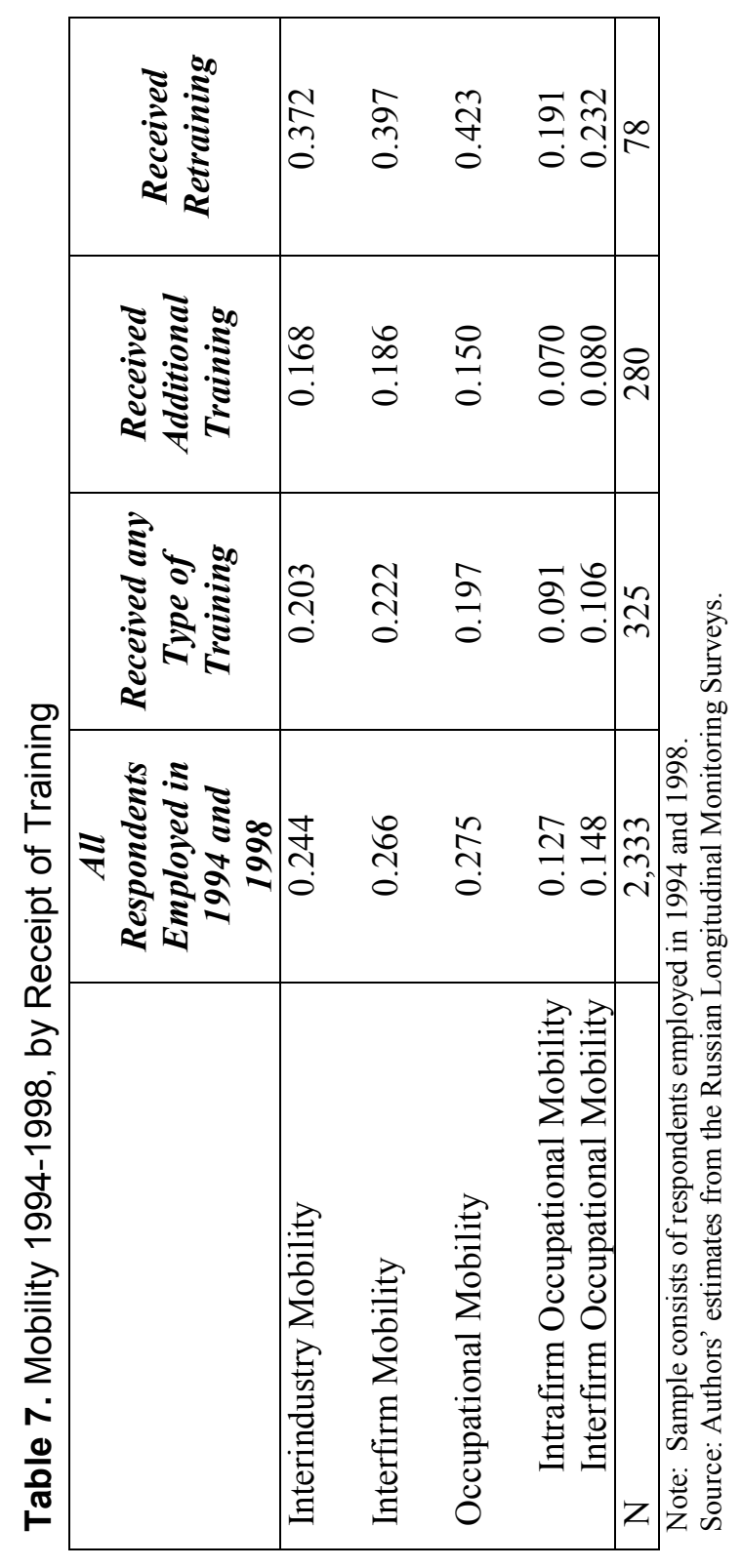


Table 8. Training and Mobility 1994-1998, Probit Estimates

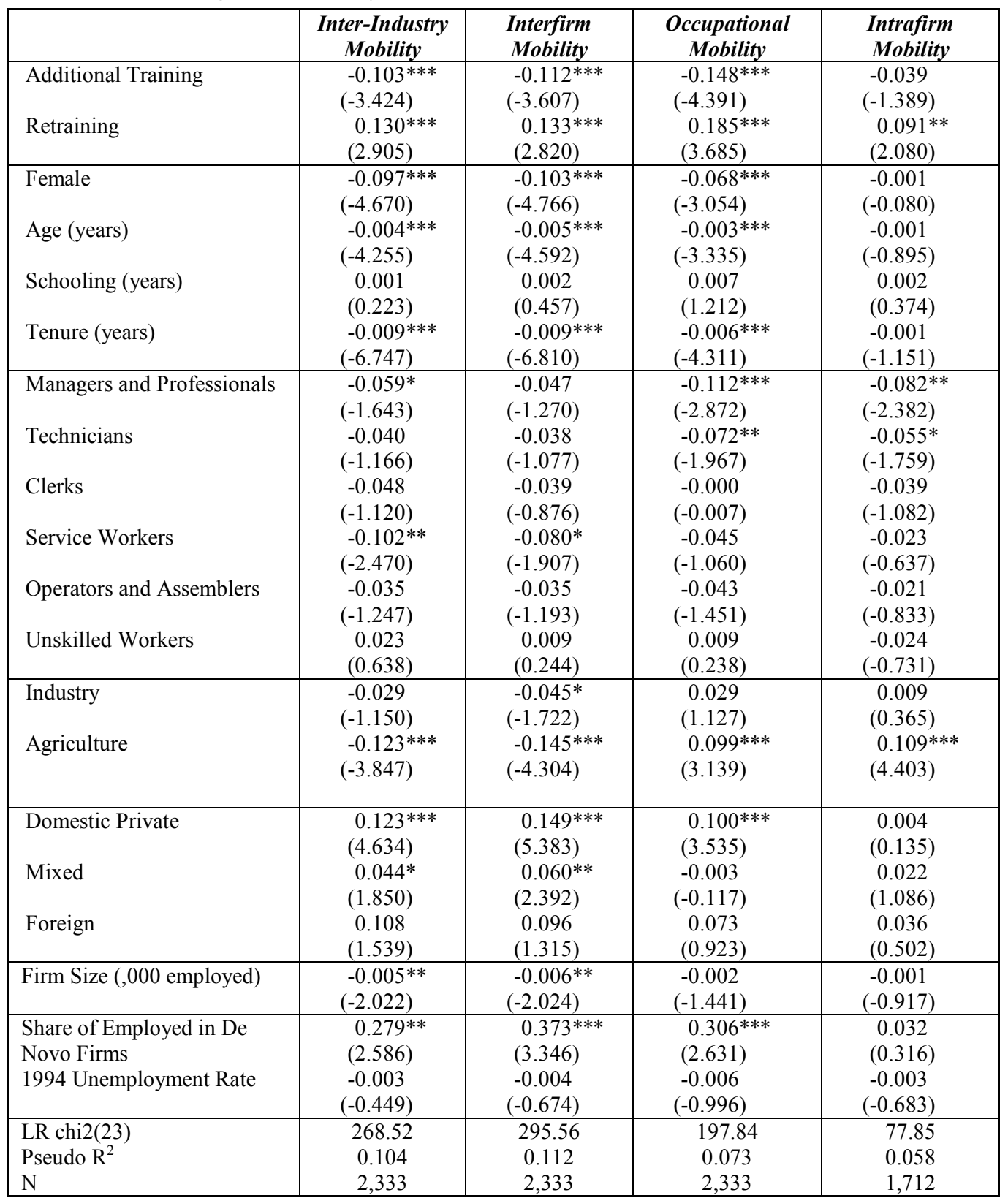

Notes: *** - significant at the $1 \%$ level, $* *$ - significant at the $5 \%$ level; *-significant at the $10 \%$ level; tstatistics are in parentheses and defined with robust standard errors. Sample consists of respondents employed in 1994 and 1998 (last column includes only those not changing firms from 1994-98). The explanatory variables except training are measured in 1994. Coefficients show the marginal effect $\mathrm{dF} / \mathrm{dX}$. Intercept and firm size missing dummy estimates are not shown.

Source: Authors' estimates from the Russian Longitudinal Monitoring Surveys. 
Table 9: Training and Employment Transitions 1994-1998, MNL Estimates

\begin{tabular}{|c|c|c|c|c|}
\hline & & $\begin{array}{c}\text { Transition to Self- } \\
\text { Employment }\end{array}$ & $\begin{array}{l}\text { Transition to } \\
\text { Unemployment }\end{array}$ & $\begin{array}{c}\text { Transition to } \\
\text { Out-of-Labor } \\
\text { Force }\end{array}$ \\
\hline 点 & $\begin{array}{l}\text { Additional Training } \\
\text { Retraining }\end{array}$ & $\begin{array}{c}-0.032 * * \\
(-1.988) \\
0.022 \\
(1.401)\end{array}$ & $\begin{array}{c}-0.018 \\
(-1.175) \\
0.042 * * * \\
(2.726)\end{array}$ & $\begin{array}{c}-0.199 * * * \\
(-4.678) \\
-0.024 \\
(-0.466)\end{array}$ \\
\hline 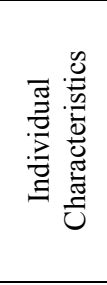 & $\begin{array}{l}\text { Female } \\
\text { Age (years) } \\
\text { Schooling (years) } \\
\text { Tenure (years) }\end{array}$ & $\begin{array}{c}-0.024^{* * *} \\
(-3.266) \\
-0.000 \\
(-1.252) \\
-0.001 \\
(-0.288) \\
-0.001^{*} \\
(-1.914)\end{array}$ & $\begin{array}{c}-0.003 \\
(-0.323) \\
-0.001 * * * \\
(-3.028) \\
-0.001 \\
(-0.633) \\
-0.001 \\
(-1.343)\end{array}$ & $\begin{array}{c}0.019 \\
(1.447) \\
0.007 * * * \\
(11.317) \\
-0.011 * * * \\
(-4.245) \\
0.000 \\
(0.456) \\
\end{array}$ \\
\hline 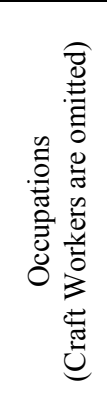 & $\begin{array}{l}\text { Managers and Professionals } \\
\text { Technicians } \\
\text { Clerks } \\
\text { Service Workers } \\
\text { Operators and Assemblers } \\
\text { Unskilled Workers }\end{array}$ & $\begin{array}{c}-0.005 \\
(-0.388) \\
-0.009 \\
(-0.711) \\
-0.016 \\
(-0.930) \\
-0.007 \\
(-0.548) \\
-0.012 \\
(-1.234) \\
-0.021 \\
(-1.529)\end{array}$ & $\begin{array}{c}-0.006 \\
(-0.363) \\
0.005 \\
(0.374) \\
-0.016 \\
(-0.835) \\
0.005 \\
(0.312) \\
-0.016 \\
(-1.203) \\
0.022 \\
(1.597)\end{array}$ & $\begin{array}{c}-0.029 \\
(-1.219) \\
0.016 \\
(0.790) \\
0.000 \\
(0.020) \\
0.014 \\
(0.619) \\
-0.035^{* *} \\
(-1.996) \\
0.016 \\
(0.795)\end{array}$ \\
\hline 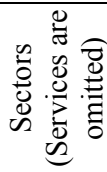 & $\begin{array}{l}\text { Industry } \\
\text { Agriculture }\end{array}$ & $\begin{array}{c}-0.012 \\
(-1.297) \\
-0.007 \\
(-0.570)\end{array}$ & $\begin{array}{c}0.005 \\
(0.465) \\
-0.016 \\
(-1.079)\end{array}$ & $\begin{array}{c}-0.018 \\
(-1.265) \\
0.021 \\
(1.370)\end{array}$ \\
\hline 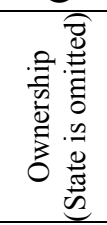 & $\begin{array}{l}\text { Domestic Private } \\
\text { Mixed } \\
\text { Foreign }\end{array}$ & $\begin{array}{c}0.035^{* * *} \\
(4.129) \\
-0.008 \\
(-0.744) \\
0.048^{* *} \\
(2.478) \\
\end{array}$ & $\begin{array}{c}0.021^{*} \\
(1.862) \\
-0.006 \\
(-0.573) \\
0.036 \\
(1.323) \\
\end{array}$ & $\begin{array}{c}0.024 \\
(1.486) \\
-0.000 \\
(-0.032) \\
-0.082 \\
(-1.164) \\
\end{array}$ \\
\hline$\stackrel{\tilde{N}}{i n}$ & $\begin{array}{l}\text { Firm Size (,000 employed) } \\
\text { Firm Size Missing Dummy }\end{array}$ & $\begin{array}{l}-0.000 \\
(-0.034) \\
0.014 * * \\
(2.008) \\
\end{array}$ & $\begin{array}{c}0.000 \\
(0.112) \\
0.003 \\
(0.359) \\
\end{array}$ & $\begin{array}{c}-0.001 \\
(-0.854) \\
0.018 \\
(1.358) \\
\end{array}$ \\
\hline శ్ర్ల & $\begin{array}{l}\text { Share of Employed in De } \\
\text { Novo Firms } \\
1994 \text { Unemployment Rate }\end{array}$ & $\begin{array}{c}-0.044 \\
(-1.090) \\
-0.003 \\
(-1.199)\end{array}$ & $\begin{array}{l}-0.037 \\
(-0.746) \\
0.004 * * \\
(2.321)\end{array}$ & $\begin{array}{c}-0.199 * * * \\
(-3.005) \\
0.012 * * * \\
(3.930)\end{array}$ \\
\hline & Intercept & $\begin{array}{c}-0.041 \\
(-1.258)\end{array}$ & $\begin{array}{l}-0.069^{*} \\
(-1.863)\end{array}$ & $\begin{array}{c}-0.349 * * * \\
(-6.955)\end{array}$ \\
\hline
\end{tabular}

Notes: *** - significant at the $1 \%$ level, ${ }^{* *}$ - significant at the $5 \%$ level; ${ }^{*}$-significant at the $10 \%$ level; tstatistics are in parentheses and defined with robust standard errors. Sample consists of respondents employed in 1994. The explanatory variables except training are measured in 1994. Training is received between 1994 and 1998. Coefficients show the marginal effect dF/dX. The base category is employed in 1994 and 1998.

Source: Authors' estimates from the Russian Longitudinal Monitoring Surveys. 
Table 10: The Impact of Training on Wage Growth, 1994-1998

Panel A: Wage Growth 1994-1998, by Receipt of Training 1994-1998

\begin{tabular}{|l|c|c|c|c|}
\hline & $\begin{array}{c}\text { All Respondents } \\
\text { Employed in 1994 } \\
\text { and 1998 }\end{array}$ & $\begin{array}{c}\text { Received any } \\
\text { Type of } \\
\text { Training }\end{array}$ & $\begin{array}{c}\text { Received } \\
\text { Additional } \\
\text { Training }\end{array}$ & $\begin{array}{c}\text { Received } \\
\text { Retraining }\end{array}$ \\
\hline Nominal Log Wage & 1.291 & 1.316 & 1.286 & 1.621 \\
Growth, 1994-1998 & $(1.001)$ & $(1.062)$ & $(1.047)$ & $(1.315)$ \\
\hline N & 2,054 & 299 & 267 & 65 \\
\hline
\end{tabular}

Note: Standard deviations are in parentheses.

Panel B: Least Squares Estimates of Logarithmic Nominal Wage Growth, 1994-1998

\begin{tabular}{|c|c|c|}
\hline Independent Variables & (1) & (2) \\
\hline Any Type of Training & $\begin{array}{l}-0.062 \\
(-0.935)\end{array}$ & \\
\hline Additional Training & & $\begin{array}{l}-0.133^{*} \\
(-1.933)\end{array}$ \\
\hline Retraining & & $\begin{array}{c}0.304^{*} \\
(1.825)\end{array}$ \\
\hline Growth Rate of Hours of Work, 1994-98 & $\begin{array}{l}0.161^{* * *} \\
(4.019)\end{array}$ & $\begin{array}{l}0.159 * * * \\
(3.982)\end{array}$ \\
\hline Hours of Work Missing & $\begin{array}{c}0.056 \\
(0.867)\end{array}$ & $\begin{array}{c}0.054 \\
(0.843)\end{array}$ \\
\hline Female & $\begin{array}{l}0.115^{* *} \\
(2.129)\end{array}$ & $\begin{array}{l}0.114 * * \\
(2.108)\end{array}$ \\
\hline Age (years) & $\begin{array}{l}-0.006 * * * \\
(-2.609)\end{array}$ & $\begin{array}{l}-0.006^{* *} \\
(-2.533)\end{array}$ \\
\hline Schooling (years) & $\begin{array}{l}-0.009 \\
(-0.690)\end{array}$ & $\begin{array}{l}-0.010 \\
(-0.724)\end{array}$ \\
\hline Tenure (years) & $\begin{array}{l}-0.008^{* * *} \\
(-2.768)\end{array}$ & $\begin{array}{l}-0.008^{* * *} \\
(-2.773)\end{array}$ \\
\hline Occupation (craft workers are omitted) & & \\
\hline Managers and Professionals & $\begin{array}{c}0.112 \\
(1.225)\end{array}$ & $\begin{array}{c}0.119 \\
(1.293)\end{array}$ \\
\hline Technicians & $\begin{array}{l}0.187^{* *} \\
(2.349)\end{array}$ & $\begin{array}{l}0.192 * * \\
(2.418)\end{array}$ \\
\hline Clerks & $\begin{array}{c}0.030 \\
(0.311)\end{array}$ & $\begin{array}{c}0.028 \\
(0.284)\end{array}$ \\
\hline Service Workers & $\begin{array}{c}-0.004 \\
(-0.040)\end{array}$ & $\begin{array}{l}-0.020 \\
(-0.210)\end{array}$ \\
\hline Operators and Assemblers & $\begin{array}{l}-0.068 \\
(-0.904)\end{array}$ & $\begin{array}{l}-0.072 \\
(-0.958)\end{array}$ \\
\hline Unskilled Workers & $\begin{array}{l}-0.021 \\
(-0.234)\end{array}$ & $\begin{array}{l}-0.022 \\
(-0.243)\end{array}$ \\
\hline Intercept & $\begin{array}{l}1.719^{* * *} \\
(8.748)\end{array}$ & $\begin{array}{l}1.716^{* * *} \\
8.724\end{array}$ \\
\hline $\begin{array}{l}\mathrm{N}=2,054 \\
\mathrm{R}^{2}\end{array}$ & $\begin{array}{l}\mathrm{F}(13,2040)=5.29 \\
0.033\end{array}$ & $\begin{array}{c}\mathrm{F}(14,2039)=5.36 \\
0.037\end{array}$ \\
\hline
\end{tabular}




\section{NOTES}

${ }^{1}$ In this case, "employed" means respondents reported having a primary job. It includes respondents that were not at work last month (for instance, on maternity leaves) and excludes respondents without a job but involved in some individual economic activity last month.

${ }^{2}$ Much of the evidence on the incidence of training in western economies pertains to formal training, largely because it is easier to measure (e.g. Lynch, 1992). Only a few surveys in the U.S. have attempted to measure informal training (e.g. the Employment Opportunity Pilot Project data, the Small Business Administration training survey data, the training supplements of the Current Population Surveys, the National Longitudinal Survey of the High School class of 1972, and National Longitudinal Survey of Youth). Loewenstein and Spletzer (1999b) discuss the difficulties of measuring informal training and the inconsistencies in the results across surveys. The evidence that does exist suggests that informal training has a high incidence rate, at least among new hires, in the U.S. economy. Using the 1992 Small Business Administration training survey, Barron, Berger, and Black (1997) find that $88.7 \%$ of new hires received informal training. However, since the work on the incidence of training is just beginning in Russia, it is natural to focus on formal training and to compare the results with those obtained for formal training in the United States.

${ }^{3}$ This is important in the case of the retraining question in the 1998 survey, in which a typographical error on the survey instrument asked about retraining in the last two years rather than the last three years. However, we believe that this mistake was corrected by interviewers, most of whom had also conducted previous waves of the survey. The fact that the training incidence rates are so similar across surveys suggests that the error was corrected and respondents correctly interpreted the question as referring to a three-year period. 


\footnotetext{
${ }^{4}$ Veum (1995) also finds evidence consistent with this idea for company provided training. In regressions explaining wage levels and wage growth, the incidence of company provided training has a positive and significant effect on wage levels and wage growth, while hours of company provided training have a very small and insignificant effect on wage levels and wage growth, consistent with a problem with error in the measurement of hours of company provided training.

${ }^{5}$ While Veum (1995), using a linear specification, finds no relationship between the receipt of company provided training and tenure, Veum (1997), using a quadratic specification, finds that additional tenure increases the probability of the receipt of company provided training at decreasing rate, similar to Bartel and Sicherman (1998) and Loewenstein and Spletzer (1999b).

${ }^{6}$ These results may be due in part to unobserved heterogeneity in the type of workers obtaining training. Because our dependent variable is wage growth rather than level, however, any fixed heterogeneity will be differenced out, leaving only heterogeneity that is correlated with the change in the value of human capital rather than the level of ability.

${ }^{7}$ One reader suggested that retraining may be more likely when an individual is faced with a larger negative shock, implying that the retraining variable is endogenous in the job mobility equations. However, this suggests that the coefficient on retraining should be biased downward in the wage growth equation. The fact that we find that retraining has a strong positive impact in the wage growth equation suggests that retraining is not only reflecting a negative shock.
} 


\section{IZA Discussion Papers}
No. Author(s)
280
P. Apps
R. Rees
281
G. Saint-Paul
282
J. Albrecht
A. Björklund
S. Vroman
283
M. Hagedorn
A. Kaul
V. Reinthaler

284

H. Rapoport

A. Weiss

285
J. Jerger
C. Pohnke
A. Spermann

286

M. Fertig

C. M. Schmidt

287

P. Guggenberger

A. Kaul

M. Kolmar

288

D. A. Cobb-Clark

289

L. Cameron

D. A. Cobb-Clark

290

D. A. Cobb-Clark

M. D. Connolly

C. Worswick

291
Title

Area

Date

Household Saving and Full Consumption over

7

04/01

the Life Cycle

Information Technology and the Knowledge

5

04/01

Elites

Is There a Glass Ceiling in Sweden?

5

04/01

Welfare Analysis in a Schumpeterian Growth

7

04/01

Model with Capital

The Optimal Size for a Minority

1

$04 / 01$

Gut betreut in den Arbeitsmarkt?

5

Eine mikroökonometrische Evaluation der

Mannheimer Arbeitsvermittlungsagentur

First- and Second-Generation Migrants in

Germany - What Do We Know and What Do

People Think

Efficiency Properties of Labor Taxation in a

3

$04 / 01$

Spatial Model of Restricted Labor Mobility

Getting Ahead: The Determinants of and Payoffs

5

04/01 to Internal Promotion for Young U.S. Men and Women

Old-Age Support in Developing Countries:

3

04/01

Labor Supply, Intergenerational Transfers and Living Arrangements

The Job Search and Education Investments of

1

04/01 Immigrant Families

Cohort Effects in the Educational Attainment of

1

05/01

Second Generation Immigrants in Germany:

An Analysis of Census Data 
N. Smith

L. Husted
G. Brunello
C. Lucifora
R. Winter-Ebmer

300
A. Stutzer
R. Lalive

301

J. R. Frick

G. G. Wagner

302

G. S. Epstein

A. Weiss

303

G. A. Pfann

B. F. Blumberg

304

P. Cahuc

E. Wasmer firm Bargaining 

H. Bonin
G. Abío
E. Berenguer
J. Gil
C. Patxot

307

G. A. Pfann

308

G. A. Pfann

D. S. Hamermesh

309

G. Brunello

310

U. Sunde

311

G. Brunello

312

C. Furnée

M. Kemler

G. A. Pfann

313

A. Ferrer-i-Carbonell

B. M.S. van Praag
Is the Deficit under Control? A Generational Accounting Perspective on Fiscal Policy and Labour Market Trends in Spain 

A. Frederiksen
E. K. Graversen
N. Smith

Works Councils and Collective Bargaining in 

A. Ibourk
B. Maillard

The Matching Efficiency of Regional Labour Models 
